\title{
2(5H)-FURANONE: A PROSPECTIVE STRATEGY FOR BIOFOULING-CONTROL IN MEMBRANE BIOFILM BACTERIA BY QUORUM SENSING INHIBITION
}

\author{
Kannan Ponnusamy ", Diby Paul, Young Sam Kim, Ji Hyang Kweon*
}

Department of Environmental Engineering, Konkuk University, 1 Hwayang-Dong, Gwangjin Gu, Seoul, 143-701, Republic of Korea.

Submitted: March 03, 2009; Returned to authors for corrections: April 14, 2009; Approved: July 24, 2009.

\begin{abstract}
Biofouling of membranes demands costly periodic cleaning and membrane replacement. A sustainable and environmentally friendly solution for maintenance is not available and would be of great interest for many purposes including economical. As complex biofilm formation by environmental strains is the major cause of biofouling and biofilm formation in most cases are controlled by $N$-Acylhomoserine lactone (AHL)mediated Quorum Sensing (QS). An effort was made to understand the appropriateness of 2(5H)-furanone, to use against biofouling of membranes. QS inhibition activity by $2(5 \mathrm{H})$-furanone was studied using bioindicator strains and known AHLs of different acyl chain lengths. The biofilm inhibition was studied by growth analysis on polystyrene plate of Aeromonas hyrdrophila, an environmental biofilm strain isolated from a bio-fouled reverse osmosis (RO) membrane. Results showed a QS inhibition activity against a wide range of AHLs and also biofilm formation by $2(5 \mathrm{H})$-furanone, which is believed to act as a potential quorum inhibition agent in a bacterial biofilm community.
\end{abstract}

Key words: Furanone, biofilm, water treatment, quorum sensing, $N$-Acyl homoserine lactone

\section{INTRODUCTION}

Biofouling is a serious problem associated with membrane processes in water technologies causing deterioration of both the quantity and quality of treated water, and consequently resulting in higher treatment costs. Biofouling is a dynamic process of microbial colonization and growth, with the formation of microbial biofilms. It results in severe performance loss, modifies membrane surface properties and demands costly periodic cleaning or membrane replacement $(8,25)$. Many studies have been focused on the alleviation of membrane fouling, for example, by backwashing, aeration, intermittent suction, module modification, addition of an inorganic coagulant and addition of a membrane fouling reducer $(1,13)$. Chlorine is the most frequently applied agent in the biofouling control, but its destructive effect on certain membrane material, especially on polyamide reverse osmosis (RO) membrane due to the residual concentration, have already been reported (31). Several antimicrobial chemical coatings have been tested on biomaterials to reduce the biofilms. Due to the toxic nature and reduced shelf life of the compounds, the need for alternative methods has become inevitable to overcome these problems.

Quorum sensing (QS) mechanisms of microorganisms are reported to be involved in the formation of biofilm, in which a quorum sensing signal molecule, an auto-inducer, functions to 
Ponnusamy, K. et al.

induce the formation of characteristic three-dimensional biofilm architecture. $N$-Acylhomoserine lactone (AHL) is the predominant signal molecule involved in QS (21) and it affects the expression of many genes and behaviors in various bacteria $(26,29,30)$. AHLs mediated gene transcription controls a variety of bacterial phenotypes $(9,28)$. The LuxI protein family synthesizes AHL, and the LuxR protein family binds AHL and regulates expression of many genes responsible for their coordinated behavior including biofilm formation (11).

An interference with this cell density-dependent communication mechanism, Quorum Quenching (QQ) has been suggested to be a promising strategy to control their coordinated behavior (6). Reduction of biofilms has been achieved by inhibition of quorum sensing due to changes in the LuxR family protein receptor for AHL signal molecules (16). Several chemicals and enzymes that target the key components of bacterial quorum sensing systems have been identified as Quorum Sensing Inhibitors (QSI) in recent years (6). A QSI system used by the marine algae Delisea pulchra has gained much interest. The algae prevent its surface colonization by other marine organisms through the production of specific defense chemical compounds called halogenated furanones (5). These furanones reside in vesicles on the surface of the algae and inhibit fouling of their surface by marine organisms. Furanones act by mimicking the AHL signal, presumably by occupying the binding site on the putative regulatory protein, rendering it highly unstable and accelerating its turnover rate and thus resulting in the rapid disruption of the quorum sensing-mediated gene regulation (7). It has been tested and used in various fields of biofilm-control. Wu et al. (32) reported that the synthetic furanones inhibited several bacterial quorum sensing and simultaneously reduced the severity of the lung infection.

The present study was focused on the use of the commercially available 2(5H)-Furanone against biofilm control. In this study, $2(5 \mathrm{H})$-furanone was tested against a wide range of individual AHL molecules to determine the QS control, as biofouling involves mixed biofilms that may have different kinds of AHLs of varying chain lengths. Furthermore
2(5H)-furanone was tested against biofilm formation in an environmental strain isolated from a fouled RO membrane. The study is supposed to lay a strong base to the knowledge on development of sustainable biofilm control.

\section{MATERIALS AND METHODS}

\section{Microorganisms and chemicals used in the study}

The bioindicator strain Chromobacterium violaceum CV026 is a mini-Tn5 mutant derived from C. violaceum ATCC 31532 (18). It is deficient in AHL production, but responds to exogenous signal molecules and produces violacein (4) and was used to screen for short chain AHLs such as (C4, C6, C8 and 3-Oxo-C8-HSL). Agrobacterium tumefaciens NTL-4 bears the plasmid pZLR4 (14) capable of producing $\beta$-galactosidase when exposed to AHLs. It was used to detect long chain AHLs (C10, C12, 3-Oxo-C12-HSL and C14-HSL) with great sensitivity (4,34). A biofilm-forming bacteria Aeromonas hydrophila isolated from a biofouled RO membrane system (Deasan, Chungbuk, Korea) was used in the study. The RO system used river water to produce highly purified water for industrial purposes. The bacterial samples were collected when the membrane system was disassembled after 4 years of operation, due to severe biofouling. All the strains were stored in LB slants (A. tumefaciens NTL-4 was maintained with gentamycin $30 \mu \mathrm{g} / \mathrm{mL}$ ) at $4^{\circ} \mathrm{C}$ and $20 \%$ glycerol stocks were maintained at $-70^{\circ} \mathrm{C}$ for long term preservation.

The quorum signal compounds $N$-butanoyl-L-homoserine lactone (C4-HSL), N-hexanoyl-L-homoserine lactone (C6HSL), $N$-octanoyl-L-homoserine lactone (C8-HSL), $N$-[3Oxooctanoyl]-L-homoserine lactone (3-Oxo-C8-HSLs), $\mathrm{N}$ decanoyl-L-homoserine lactone (C10-HSL), N-dodecanoyl-Lhomoserine lactone (C12-HSL), $N$-tetradecanoyl-L-homoserine lactone (C14-HSL) and 2(5H)-furanone were procured from Sigma-Aldrich. $\quad N$-[3-oxododecanoyl]-L-homoserine lactone (3-Oxo-C12-HSL) was purchased from Cayman chemicals. All other chemicals and glassware unless otherwise stated, have been obtained from Sigma-Aldrich. 


\section{Bioassay for Inhibition of Quorum Sensing}

The QS based functions viz. violacein production in CV026 and $\beta$-Galactosidase production in NTL4, in the presence of 2(5H)-Furanone were estimated. CV026 was used for experiments with short chain AHLs and NTL4 for long chain AHLs.

Violacein Unit assay: The experiment was conducted in 96 well microtiter plates. Different sub MIC concentrations of the $2(5 \mathrm{H})$-furanone were added to the wells containing $\mathrm{LB}$ and inoculated with $1 \%$ of overnight grown $C$. violaceum 026 . Individual AHLs $(10 \mu \mathrm{M})$ were pipetted separately to the medium. The final volume was maintained to $100 \mu \mathrm{L}$. The plates were incubated at $30^{\circ} \mathrm{C}$ at $150 \mathrm{rpm}$ for $18 \mathrm{~h}$. Population density of cells was determined at $660 \mathrm{~nm}$. In order to estimate violacein, $100 \mu \mathrm{L}$ of culture was transferred into $1.5 \mathrm{ml}$ microfuge tube. The cells were lysed by adding equal volume of $10 \%$ SDS and mixed well with a vortex mixer (Vision Scientific co. Ltd.) for $5 \mathrm{~s}$ and incubated at room temperature $\left(28^{\circ} \mathrm{C}\right)$ for $5 \mathrm{~min}$. Violacein was quantitatively extracted from the lysed cell lysates by adding $450 \mu \mathrm{L}$ of water-saturated butanol and vortexed for $5 \mathrm{~s}$. The organic phase was separated by centrifugation at $12,000 \mathrm{rpm}$ for $5 \mathrm{~min}$. The upper phase, butanol containing violacein was read at $585 \mathrm{~nm}$ using micro plate reader (Biotek). The violacein unit was calculated as $\left(\mathrm{A}_{585} / \mathrm{A}_{660}\right) \times 1000$, according to Blosser and Gray (3).

$\boldsymbol{\beta}$-Galactosidase assay: The QSI effect of $2(5 \mathrm{H})$-furanone against long chain AHLs was determined by growing $A$. tumefaciens NTL-4 on microtiter plates containing LB medium with $10 \mu \mathrm{M}$ of each AHLs and various concentrations (1 to $0.03125 \mathrm{mg} / \mathrm{mL})$ of $2(5 \mathrm{H})$-furanone. The cell density was determined upon 12 h. $20 \mu \mathrm{L}$ of the culture was mixed with 80 $\mu \mathrm{l}$ of permeabilization solution $\left(100 \mathrm{mM} \mathrm{Na} \mathrm{HPO}_{4} ; 20 \mathrm{mM}\right.$ $\mathrm{KCl} ; 2 \mathrm{mM} \mathrm{MgSO}_{4} ; 0.8 \mathrm{mg} / \mathrm{mL} \mathrm{CTAB} ; 0.4 \mathrm{mg} / \mathrm{mL}$ sodium deoxycholate; $5.4 \mu \mathrm{L} / \mathrm{mL} \quad \beta$-mercaptoethanol) in a $1.5 \mathrm{~mL}$ microfuge tubes. All the samples and substrate solution (60 $\mathrm{mM} \mathrm{Na}_{2} \mathrm{HPO}_{4} ; 0 \mathrm{mM} \mathrm{NaH} \mathrm{PO}_{4} ; 1 \mathrm{mg} / \mathrm{mL} \mathrm{ONPG} ; 2.7 \mu \mathrm{L} / \mathrm{mL}$ $\beta$-mercaptoethanol) were transferred to $30^{\circ} \mathrm{C}$ incubator for 20 30 minutes. $600 \mu \mathrm{L}$ of the substrate solution was added to each tube and the time of addition was noted. After sufficient color was developed, the reaction was stopped with $700 \mu \mathrm{L}$ of stop solution ( $1 \mathrm{M} \mathrm{Na}_{2} \mathrm{CO}_{3}$ ), mixed well and the stop time was noted. The tubes were centrifuged at $12,000 \mathrm{rpm}$ for $5 \mathrm{~min}$ to remove the cell debris. $100 \mu \mathrm{L}$ of the supernatant was transferred to a fresh 96 well plates and read at $420 \mathrm{~nm}$. The Miller Units was calculated using the following formula $\left[\mathrm{A}_{420} /\left(\mathrm{A}_{600} \times 0.02 \mathrm{~mL} \times\right.\right.$ reaction time $\left.)\right] \times 1000(33)$.

\section{2(5H)-Furanone-mediated Biofilm inhibition}

The biofilm formation of the environmental strain, $A$. hydrophila, on polystyrene surface was studied using sterile, 96-well round bottom microtiter plate with lid (total volume: $360 \mu \mathrm{L}$ ) (SPL life sciences, Seoul, Korea). As one of our studies with LB medium at $30^{\circ} \mathrm{C}$ showed that A. hydrophila produced maximum biofilm on a polystyrene surface at $6 \mathrm{~h}$ of incubation (data not published), the strain was grown in $200 \mu \mathrm{L}$ of LB medium taken in wells of polystyrene microplates for $6 \mathrm{~h}$, after amending the media with various concentrations of 2(5H)-Furanone. After the incubation period, the planktonic cell (growth was measured at $600 \mathrm{~nm}$ ) and medium were poured off. Biofilm mass was quantified by Crystal violet staining method, as described by Stepanovic et al. (27). The wells were washed three times with distilled water, $200 \mu \mathrm{L}$ of methanol (99\%) was added to each well and allowed for 15 min to fix the adhered biofilms. Methanol was poured off and the plate was air dried. $200 \mu \mathrm{L}$ of Huckers's crystal violet $(2 \%)$ was added to the wells and after $5 \mathrm{~min}$, the excess crystal violet was removed by washing the plates gently. Finally, the crystal violet was dissolved in $200 \mu \mathrm{L}$ of $33 \%$ acetic acid (v/v). The absorbance was measured at $570 \mathrm{~nm}$. Appropriate controls were maintained. The crystal violet absorbance was normalized with the biofilm activity.

\section{Statistical analysis}

Statistical significance was determined using One-way analysis of variance (ANOVA). Values with $p<0.05$ were considered as significance $(n=6)$. 


\section{RESULTS AND DISCUSSION}

The discovery of the biofilm regulatory mechanism, quorum quenching, afforded a novel opportunity to control unwanted microbial activity without the use of growth inhibitory agents such as antibiotics and disinfectants or any toxic chemicals. Certain natural compounds or synthetic analogs that function as Quorum Sensing Inhibition (QSI) compounds have been reported to have potential applications (17). In the present study, 2(5H)-Furanone was tested against QS mediated through different AHLs of varying acyl chain lengths, as an environmental biofilm constitute many different genera and species of microorganisms producing various types of AHLs (multiple QS molecule in mixed biofilm environment). As suggested by Mok et al. (20), an investigation of QSI compounds against various autoinducer molecules is expected to provide potential tools against bacteria using multiple types of autoinducers to regulate a single phenotype.

Even though our study was not intended directly on the quantitative response of various AHLs on violacein synthesis in CV026, it was observed that the quantity of violacein varied with the type of AHL (in terms of acyl chain length), highest being with C8 HSL and lowest with C4 HSL, among the short chain AHLs. Halogenated furanones from Delisea pulchra are well described as antagonists to $N$-acyl homoserine lactones (16) and our results showed that AHL-induced violacein production in CV026 was drastically and significantly reduced with $2(5 \mathrm{H})$-furanone $(1 \mathrm{mg} / \mathrm{mL})$, when CV026 was grown separately in presence of various short chain AHLs (C4-HSL, C6-HSL, C8-HSL, 3-Oxo-C8-HSL) (Fig. 1). As low as a concentration of $0.2 \mathrm{mg} / \mathrm{mL}$ of $2(5 \mathrm{H})$-furanone initiated to inhibit the AHL mediated and QS regulated synthesis of violacein in CV026. Although our results did not directly demonstrate how 2(5H)-furanone inhibited QS mediated violacein synthesis in CV026, they showed that $2(5 \mathrm{H})$ furanone acted in a dosage-dependent manner towards QQ. $2(5 \mathrm{H})$-furanone-mediated reduction in violacein synthesis varied with lengths of acyl chain of AHLs. With all AHLs, $2(5 \mathrm{H})$-furanone brought down the violacein synthesis to significantly. Rasmussen et al. (23) have reported similar finding of inhibition of short chain AHL-mediated coordination behaviors in Serratia liquefaciens with furanones. According to Eberl et al. (7), furanone acts by mimicking the AHL signal, thereby occupying the binding site on the putative regulatory protein rendering it highly unstable and accelerating its turnover rate and thus resulting in the rapid disruption of the quorum-sensing-mediated gene regulation. Manefield et al. (16) suggested that the furanones compete with AHLs for a common binding site on LuxR and LuxR homologues. The dose dependent manner of action of $2(5 \mathrm{H})$-furanone in our study supported the view that furanones could be displacing the AHL signals from the LuxR protein, thus preventing their coordinated behavior.

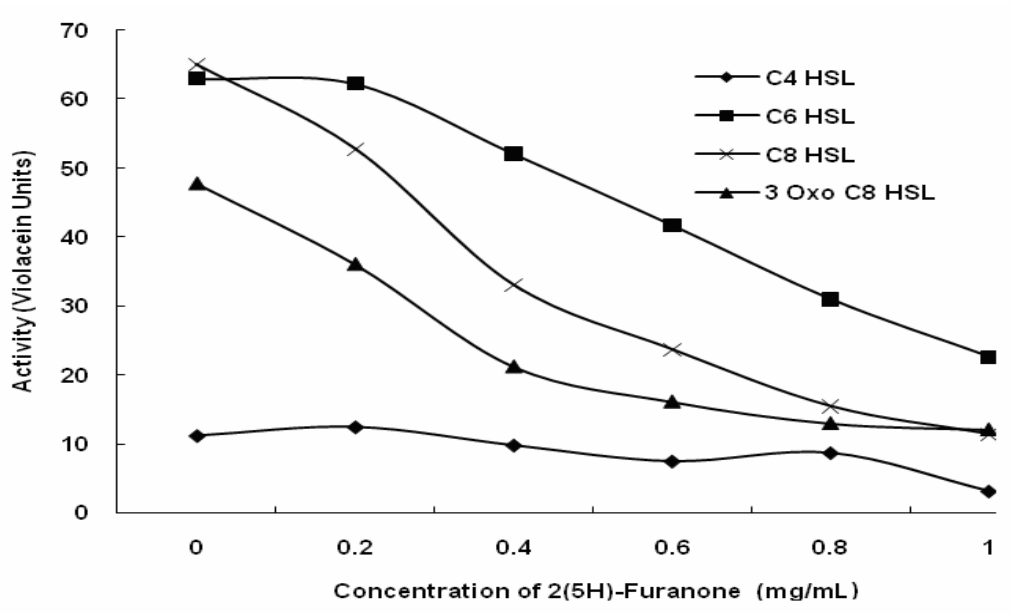

Figure 1. Quorum sensing inhibition property of $2(5 \mathrm{H})$-furanone against short chain AHLs in Chromobacterium violaceum $\mathrm{CV} 026$. 
In the long chain AHLs, production of $\beta$-galactosidase by NTL4 was inhibited in different levels depending on $2(5 \mathrm{H})-$ furanone concentrations $(0.4,0.6,0.8$ and $1 \mathrm{mg} / \mathrm{mL}$ ) (Fig. 2). The minimum concentration of $2(5 \mathrm{H})$-furanone required for a significant quorum inhibition activity was observed to be 0.4 $\mathrm{mg} / \mathrm{mL} .2(5 \mathrm{H})$-furanone $(1 \mathrm{mg} / \mathrm{mL})$ showed $52 \%$ and $46 \%$ QS inhibition when exposed to the signal molecules C12-HSL and C14-HSL, respectively. However, when the AHLs were C10HSL and 3-oxo-C12-HSL, 2(5H)-furanone showed meager inhibition of $\beta$-galactosidase production.

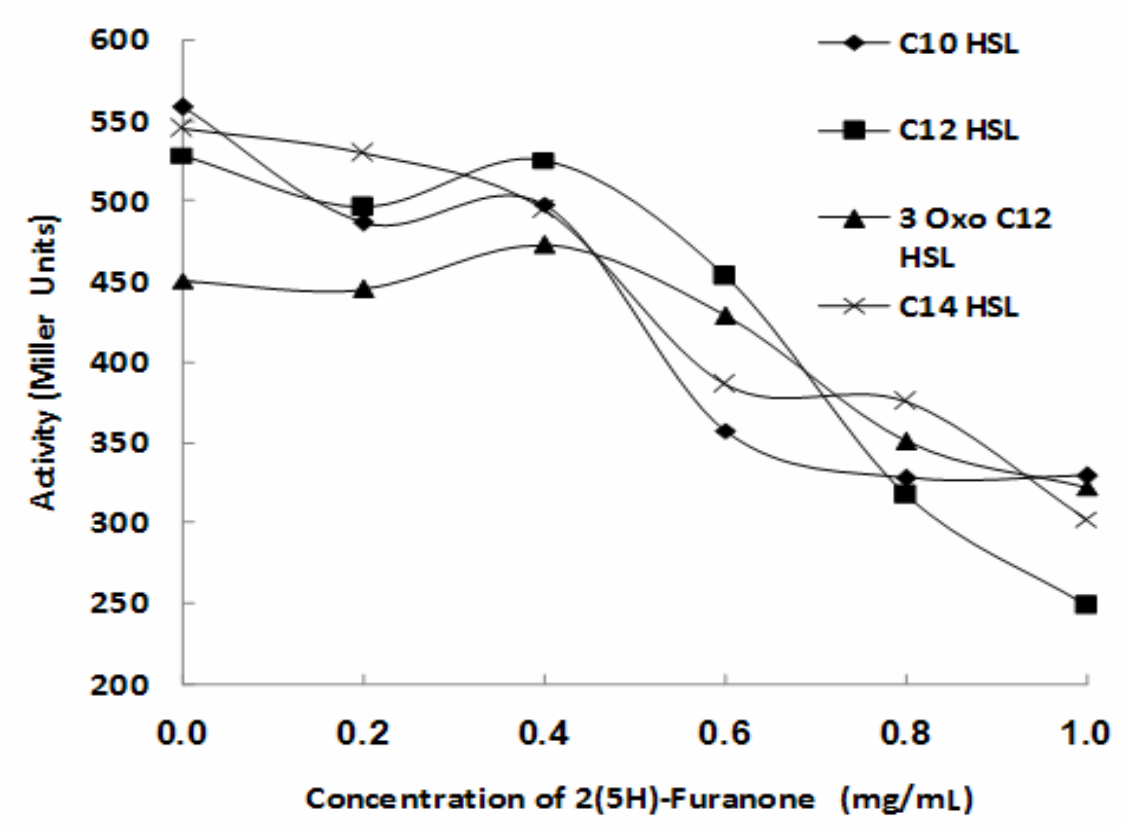

Figure 2. Quorum sensing inhibition property of 2(5H)-furanone against long chain AHLs in Agrobacterium tumefaciens NTL-4.

Minimum Inhibitory Concentration (MIC) of 2(5H)furanone against CV026 and A. hydrophila was found to be $\geq 1$ $\mathrm{mg} / \mathrm{mL}$. 2(5H)-furanone at the tested concentrations (up to 1 $\mathrm{mg} / \mathrm{mL}$ ) did not show antagonistic effects on growth of CV026. It is therefore assumed that the Furanone-mediated reduction in violacein and $\beta$-galacosidase synthesis were not due to inhibition of growth processes, but rather based on interferences with the signaling system of quorum sensing. Martinelli et al. (17) made similar observations and reported that furanone at low concentrations is not antagonistic to bacteria.

According to Lynch et al. (15) and the results found in this work at the bioassay for inhibition of quorum-sensing, probably the environmental biofouling bacteria demonstrated an interference of AHLs action by $2(5 \mathrm{H})$-furanone and probably this is the cause of the biofilm development inhibition. As low as a concentration of $0.2 \mathrm{mg} / \mathrm{mL}$ of $2(5 \mathrm{H})-$ furanone brought down the biofilm mass on the polystyrene surface to $17 \%$ (Fig. 3). A further increase in concentration of Furanone until $0.8 \mathrm{mg} / \mathrm{mL}$ did not support further reduction in biofilm formation. However with $1 \mathrm{mg} / \mathrm{mL}$ concentration there was significant (32\%) reduction in QS mediated biofilm formation. The level of biofilm formation depends on the surface material property and various environmental factors (22). In this study we did not perform a detailed study on surface property of biofilm formation; however this study focused and evidenced that furanone inhibits the QS molecules with varying chain lengths. Furanone mediated QQ activity has been reported to be effective in many different fields. It has been reported to inhibit QS in a number of bacteria $(10,23)$. Furanone-imposed 
Ponnusamy, K. et al.

inhibition of colonization of marine bacteria (23) and inhibition of biofilm formation by Pseudomonas aeruginosa (24) have been reported. Baveja et al. (2) reported the efficacy of furanones, physically absorbed to different biomaterials, to reduce the adhesion and colonization of Staphylococcus epidermidis in vitro.

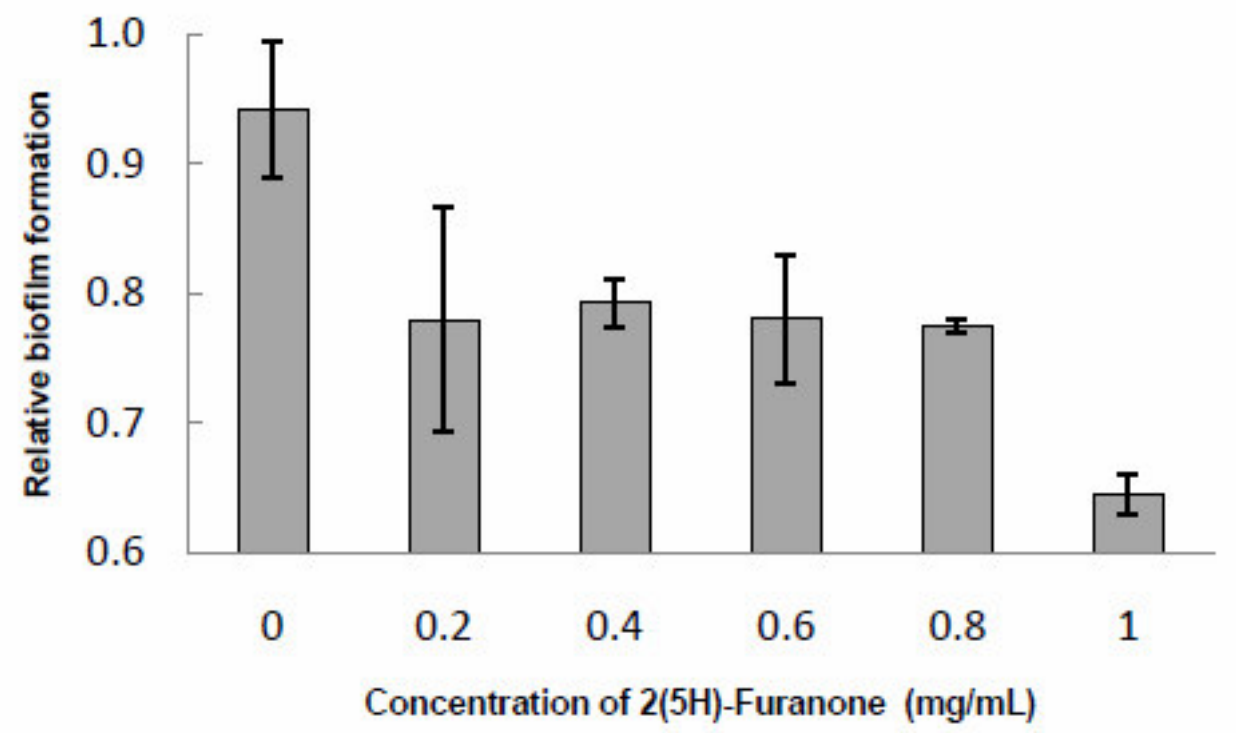

Figure 3. 2(5H)-furanone interfered with the actions of AHL molecules and inhibited QS mediated biofilm-formation in the environmental strain, Aeromonas hydrophila on polystyrene surface. Vertical bars represent the standard deviations of the mean from six replicates.

The short and long chain AHLs were inhibited by $2(5 \mathrm{H})$ furanone suggests that it could be a potential quorum quenching agent in a mixed bacterial community. As suggested by Rasmussen et al. (23), the inhibition of intercellular communication is not limited to one species but extends to cover even interspecies communication. This may have great impact in natural habitats where different species, which can co-operate using AHL signal molecules, are present in microniches (19). With this background, 2(5H)-furanone could be considered as an appropriate agent that can be further studied to control biofouling in membranes, used in water and waste water treatment systems. As many furanones with chemical structures similar to the $N$-acylhomoserine lactones are produced in nature and have been detected to be antagonistic to QS, it could also be taken as a nature-friendly method. Also as suggested by Kjelleberg et al. (12), furanones are unlikely to induce bacterial resistance as their mechanism of action is not to kill bacteria but to inhibit bacterial growth. The fact that furanones still act as effective quorum quenching agents when coated to various surfaces (2) adds to the scope of the technology. Further experiments are necessary in order to confirm the effectiveness of the compound against biofilm formation in actual membranes.

\section{CONCLUSIONS}

Our results showed that $2(5 \mathrm{H})$-furanone inhibited quorum sensing mediated behaviors by interfering with various AHL signal compounds of different acyl chain lengths. It indicates that this compound can be an effective QS inhibition against many different bacterial genera that produce different types of AHL signal molecules. To confirm, 2(5H)-furanone also reduced the QS mediated biofilm formation in the wild strain of A. hydrophila (isolated from a bio-fouled RO 
membrane) significantly. Furanones have been extensively used for biofilm control in medical catheters and various other fields. It can be a possible alternative for the present chemical control strategies for biofouling control in membrane systems. The present experiments need to be extrapolated further in order to have a better understanding about the suitability of the technology under field conditions. The efficacy of the compound against biofilm consortia formed by multiple bacterial strains deserves close attention. Also, development of a 'slow release (of the compound) system' needs further investigation.

\section{ACKNOWLEDGEMENTS}

The financial aid from the Korea Science and Engineering Foundation (KOSEF), Ministry of Science and Technology, Republic of Korea is gratefully acknowledged.

\section{REFERENCES}

1. Baker, J.S.; Dudley, L.Y. (1998). Biofouling in membrane system-a review. Desalination., 118, 81-90.

2. Baveja, J.K.; Willcox, P.; Hume, E.B.H.; Kumar N.; Odell, R.; PooleWarren, L.A. (2004). Furanones as potential anti-bacterial coatings on biomaterials. Biomaterials., 25(20), 5003-5012.

3. Blosser, R.S.; Gray, K.M. (2000). Extraction of violacein from Chromobacterium violaceum provides a new quantitative bioassay for $\mathrm{N}$ acyl homoserine lactone autoinducers. J. Microbiol. Methods., 40(1), 4755.

4. Cha, C.; Gao, P.; Chen, Y.C.; Shaw, P.D.; Farrand, S.K. (1998). Production of acyl-homoserine lactone quorum-sensing signals by gramnegative plant associated bacteria. Mol. Plant-Microbe Interact., 11, 1119-1129.

5. de Nys R.; Wright, A.D.; Konig, G.M.; Sticher, O. (1993). New halogenated furanones from the marine alga Delisea pulchra (cf. fimbriata). Tetrahedron.,49, 11213-11220.

6. Dong, Y.H.; Zhang, L.H. (2005). Quorum sensing and quorumquenching enzymes. J. Microbiol., 43, 101-109.

7. Eberl, L.; Molin, S.; Givskov, M. (1999) Surface motility of Serratia liquefaciens MG1. J. Bacteriol., 181, 1703-1712.

8. Flemming, H.C.; Scaule, G.; Griebe, T.; Schmitt, J.; Tamachkiarowa, A. (1997). Biofouling-the Achilles heel of membrane processes. Desalination., 113, 215-225.

9. Fuqua, C.; Winans, S.C. (1996). Conserved cis-acting promoter elements are required for density-dependent transcription of Agrobacterium tumefaciens conjugal transfer genes. J. Bacteriol., 178(2), 435-440.
10. Gram, L.; de Nys, R.; Maximilien, R.; Givskov, M.; Steinberg, P.; Kjelleberg, S. (1996). Inhibitory effects of secondary metabolites from the red alga Delisea pulchra on swarming motility of Proteus mirabilis. Appl. Environ. Microbiol., 62(11), 4284-4287.

11. Greenberg, E.P. (1997). Quorum sensing in gram-negative bacteria. ASM News., 63, 371-377.

12. Kjelleberg, S.; Steinberg, P. (2002). Defenses against bacterial colonization of marine plants. In SE Lindow, E Poinar, V Elliott, eds, Phyllosphere Microbiology. American Phytopathological Society Press, Minneapolis.

13. Lee, W.N.; Chang, I.S.; Hwang, B.K.; Park, P.K.; Lee, C.H.; Huang, X. (2007). Changes in biofilm architecture with addition of membrane fouling reducer in a membrane bioreactor. Process Biochemistry., 42, $655-661$.

14. Luo, Z.; Su, S.; Farrand, S.K. (2003). In situ activation of the quorumsensing transcription factor TraR by cognate and noncognate acylhomoserine lactone ligands: kinetics and consequences, J. Bacteriol. 185, $5665-5672$

15. Lynch, M.J.; Swift, S.; Kirke, D.F.; Keevil, C.W.; Dodd, C.E.R.; Williams, P. (2002). The regulation of biofilm development by quorum sensing in Aeromonas hydrophila. Environ Microbiol., 4, 18-28.

16. Manefield, M.; de Nys. R.; Kumar, N.; Read, R.; Givskov, M.; Steinberg, P.; Kjelleberg, S. (1999). Evidence that halogenated furanones from Delisea pulchra inhibit acylated homoserine lactone (AHL)- mediated gene expression by displacing the AHL signal from its receptor protein. Microbiology., 145, 283-291.

17. Martinelli, D.; Grossmann, G.; Sequin, U.; Brandl, H.; Bachofen R. (2004). Effects of natural and chemically synthesized furanones on quorum sensing in Chromobacterium violaceum. BMC Microbiology., 4, 25.

18. McClean, K.H.; Winson, M.K.; Fish, L.; Taylor, A.; Chhabra, S.R.; Camara, M.; Daykin, M.; Lamb, J.H.; Swift, S.; Bycroft, B.W.; Stewart, G.S.A.B.; Williams, P. (1997). Quorum sensing and Chromobacterium violaceum:Exploitation of violacein production and inhibition for the detection of $N$-acylhomoserine lactones. Microbiology., 143, 3703-3711.

19. McKenney, D.; Brown, K.; Allison, D.G. (1995). Influence of Pseudomonas aeruginosa exoproducts on virulence factor production in Burkholderia cepacia: evidence of interspecies communication. J. Bacteriol., 177(23), 6989-6992.

20. Mok, K.C.; Wingreen, N.S.; Bassler, B.L. (2003). Vibrio harveyi quorum sensing: a coincidence detector for two autoinducers controls gene expression. EMBO J., 22, 870-881.

21. Morohoshi, T.; Shiono, T.; Takidouchi, K.; Kato, M.; Kato, N.; Kato, J.; Ikeda, T. (2007). Inhibition of quorum sensing in Serratia marcescens AS-1 by synthetic analogs of N-Acylhomoserine lactone. Appl. Environ. Microbiol., 73(20), 6339-6344.

22. Pizzolitto, E.L.; Pizzolitto, A.C.; Pozetti, G.L. (2001). Chemical and microbiological evaluation of the internal surfaces of aluminum tubes 
Ponnusamy, K. et al.

both unlined and lined with epoxi resin by means of the stereoscope and scanning electron microscope. Br. J. Microbiol., 32, 340-344.

23. Rasmussen, T.B.; Manefield, M.; Andersen, J.B.; Eberl, L.; Anthoni, U.; Christophersen, C.; Steinberg, P.; Kjelleberg, S.; Givskov, M. (2000). How Delisea pulchra furanones affect quorum sensing and swarming motility in Serratia liquefaciens MG1. Microbiology., 146, 3237-3244.

24. Read, R.; Kumar, N.; Willcox, M.D.P.; Zhu, H.; Griesser, H.; Muir, B.; Thissen, H.; Hughes, T. (2001). Antimicrobial coatings, PCT International Application., PQ6812.

25. Ridgway, F.R.; Flemming, H.C. (1996). Membrane biofouling. In: Mallevialle, P.E.O., Wiesner, M.R. (Eds.), Water Treatment Membrane Processes. McGraw-Hill, New York, NY, pp. 6.1-6.62.

26. Schuster, M.; Lostroh, C.P.; Ogi, T.; Greenberg, E.P. (2003). Identification, timing, and signal specificity of Pseudomonas aeruginosa quorum-controlled genes: a transcriptome analysis. J. Bacteriol., 185(7), 2066-2079.

27. Stepanovic, S.; Vukovic, D.; Dakic, I.; Savic, B.; Svabic-Vlahovic, M. (2000). A modified microtiter-plate test for quantification of staphylococcal biofilm formation. J. Microbiol. Methods 40, 175-179.

28. Swift, S.; Fish, L.; Camara, M.; Winson, M.K.; Bycroft, B.W.; Williams, P.; Stewart, G.S. (1996). Quorum sensing in Aeromonas: identification and characterisation of the LuxRI homologous cassette, AhyRI in Aeromonas hydrophila. In Abstracts of the 96th General Meeting of the
American Society for Microbiology. American Society for Microbiology, Washington, D.C. H-208, p. 520.

29. Wagner, V.E.; Bushnell, D.; Passador, L.; Brooks, A.I.; Iglewski, B.H. (2003). Microarray analysis of Pseudomonas aeruginosa quorum-sensing regulons: effects of growth phase and environment. J. Bacteriol., 185, 2080-2095.

30. Whitehead, N.A.; Barnard, A.M.L.; Slater, H.; Simpson, N.J.L.; Salmond, G.P.C. (2001). Quorum-sensing in gram-negative bacteria. FEMS Microbiol. Rev., 25, 365-404.

31. Wintgens, T.; Rosen, J.; Melin, T.; Brepols, C.; Drensla, K.; Engelhardt, N. (2003). Modeling of a membrane bioreactor system for municipal wastewater treatment. J. Membr. Sci., 216, 55-56.

32. Wu, H.; Song, Z.; Hentzer, M.; Andersen, J.B.; Molin, S.; Givskov, M.; Hoiby, N. (2004). Synthetic furanones inhibit quorum-sensing and enhance bacterial clearance in Pseudomonas aeruginosa lung infection in mice. J Antimicrob Chemother., 53(6), 1054-1061.

33. Zhang, X.; Bremer, H. (1995). Control of the Escherichia coli rrnB P1 promoter strength by ppGpp. J. Biol. Chem., 270(19), 11181-11189.

34. Zhu, J.; Beaber, J.W.; Moré, M.I.; Fuqua, C.; Eberhard, A.; Winans, S.C. (1998). Analogs of the autoinducer 3-oxooctanoyl-homoserine lactone strongly inhibit activity of the TraR protein of Agrobacterium tumefaciens. J. Bacteriol., 180(20), 5398-5405. 